\title{
Feasibility Study of using Flexible Solar Panels for Powered-Parachute Flying Vehicles
}

\author{
Hanafy M. Omar*, Saad M. Mukras and Abdulaziz S. Alaboodi \\ Department of Mechanical Engineering, Qassim University, Saudi Arabia; hanafy@qec.edu.sa, mukras@qec.edu.sa, \\ alaboodi@qec.edu.sa
}

\begin{abstract}
Objectives: To assess the potential of using the flexible solar cells to provide the powered parachute vehicles (PPC) with the necessary power for cruise flight. Methods/Analysis: The power required for a typical PPC with three different types of flexible solar cells was determined based on the actuator disk theory. The necessary area and mass of the solar cells needed to generate the required power are also determined. Findings: It was found that the available solar cells in the market can be used to cover the PPC parafoil and generate the required power. However, there is a trade-off between the efficiency, flexibility, and cost of the solar cells. Application/Improvement: The proposed idea of covering the parafoil's surface with solar cells, with the aim of increasing the endurance of the PPC vehicles, was found to be feasible. This technology can be adopted for military and civilian applications.
\end{abstract}

Keywords: Parafoil, Paraglider, Powered Parachute, Solar, Solar Powered

\section{Introduction}

A powered parachute (PPC) is an unconventional aircraft that consists of a frame (usually made of metal, wood or plastic), a ram air parachute (parafoil) and a propeller that is driven by a piston or electric motor (Figure 1). In contrast to conventional aircrafts, PPC uses parachutes instead of fixed rigid wings to produce the lift. To achieve flight, thrust from propellers causes the PPC to advance forward which intern causes the parachute to generate lift and thus enabling the PPC to takeoff. The PPC is controlled by steering the parachute right or left to make turns. Climb and descent is achieved by adjusting the engine power. This makes controlling the PPC easier than controlling a typical aircraft since PPCs do not have control surfaces such us ailerons, rudders or elevators ${ }^{1}$.

Currently, powered parachute vehicles are used widely in sports, recreation activities as well as in military applications $s^{2}$. In these applications the duration of the flight is limited. Due to the advantages of this kind of vehicle

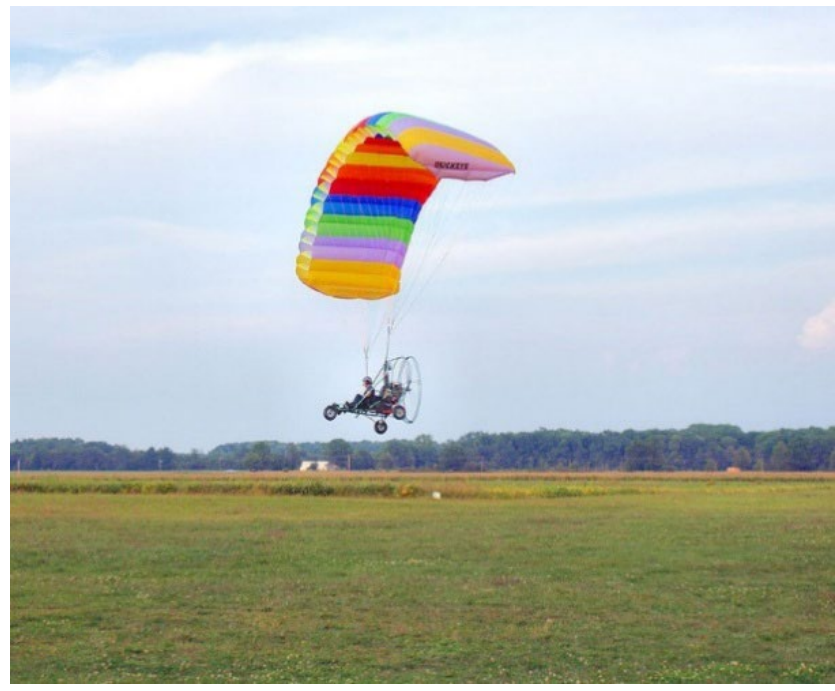

Figure 1. Powered Parachute Vehicle.

over the fixed wing aircraft and the rotor craft, it can also be used in photographing and reconnaissance. In these promising applications, the powered parachute should be autonomous and exhibit extended flight range. 
Flying vehicles with infinite endurance is indeed a dream for aircraft designers and manufacturers. The use of solar energy as a means to achieve this dream has been proposed in numerous projects ${ }^{3-6}$. However, none of these projects have investigated the usage of solar energy for PPC. The PPC has a large surface area on its parafoil, therefore there is a good potential to generate the power required to fly this vehicle from solar panels fixed on the surface of the parachute. These panels should be flexible to enable them to conform to the shape of the parachute. Advances in the development of flexible solar panels make the proposed idea feasible. In the following section, a brief history of developing solar-powered flying vehicles is presented.

Research and development of solar-powered aircraft have gradually gained interest over the past 40 years. These efforts have mainly been geared at developing more environmentally friendly vehicles as well as increasing the mission ranges. The first solar-powered aircraft was flown in $1974^{3}$. The aircraft which was named, Sunrise I, consisted of approximately 4096 solar cells (producing 450 W) and weighed about $12.4 \mathrm{~kg}(27.5 \mathrm{lb})$. In 1975, Sunrise II was built and comprised of 4480 solar cells capable of producing 600 W. Later in 1976, Solaris, built by Fred Milikty, was able to fly for a short period and attain an altitude of about $50 \mathrm{~m}^{4}$. This marked the initial years of development of solar-powered aircraft.

As research in solar powered aircrafts continued, confidence in solar-powered flight grew. A new challenge emerged, that of manned flight of solar-powered aircraft. The Gossamer Penguin, developed by Dr. Paul MacCready in 1980 became the first manned solar-powered aircraft to demonstrate flight, making a $2.6 \mathrm{~km}$ lowaltitude flight ${ }^{5-6}$. This was later (in 1981) followed by the development of the Solar Challenger which comprised of 16000 solar cells and produced about $2500 \mathrm{~W}$ of power ${ }^{7}$. Gunter Rochelt developed the Solair I, approximately the same time, and in 1983 it made a successful attempt to cross the English Channel. The Solair was covered with a total of 2499 solar cells producing $1800 \mathrm{~W}$ of power. Between 1986 and 1989 Eric Raymond developed the Sunseeker in the US which was flown as a glider in 1989 and in 1990 it crossed the US completing 121 hours in the air in 21 solar powered flights ${ }^{6}$.

A number of unmanned solar-powered aircraft were developed in the early periods of solar-powered aircraft research. The most notable among them are the Pathfinder in 1995 followed by the Pathfinder Plus in 1998, as well as the Helios ad Centurion in the early $2000^{3} \mathrm{~s}^{6}$. These fol- lowed on from the success of the Solar Challenger after which the US government provided funding to Aero Vironment Inc. to conduct a feasibility study on longduration solar-powered flight. The Helios was intended to be an ultimate solar-powered aircraft in that it utilized solar energy for flight in the day and stored energy for night flight. It, however, experienced structural failure and proved unsustainable?

Recent efforts have seen the development of more mature solar powered aircrafts. These include the Solong that in 2005 endured $48 \mathrm{~h}$ of flight as well as the British Qineti Zephyr in 2007 that completed a $58 \mathrm{~h} \mathrm{flight}^{6}$. Other recent solar-powered aircraft include the Sky-Sailor by Noth $^{7}$ (which in 2008 completed more than $27 \mathrm{~h}$ of flight over $874 \mathrm{~km}$ ) and the Solar-Impuse by BetandPiccar and Andre Broschberg (which in 2010 completed a 26h flight) ${ }^{6}$.

The objective of this work is to assess the potential of using the available solar cells in the market to provide the power required to fly a PPC with a small payload such as a high-resolution camera.

The paper is organized as follows: the equations that govern the vehicle motion and determine the power are given in section 2, a survey of the existing solar cells is presented in section 3 followed by the numerical calculation in section 4, finally, the conclusion of the work is given in section 5 .

\section{Power Requirement}

It is assumed that the powered parachute vehicle will be used for photographing and monitoring moving targets. Therefore, the payload will be a high-resolution camera in addition to the equipment needed to fly the vehicle such as the motor, battery, communication modules, microcontroller, and servomotors. Based on the weight of the equipment and the weight of the structural elements (frame, wheels, steering bars, landing mechanism), the size of the parachute needed to produce the lift will be determined. Software such as gliderplan ${ }^{(\mathrm{R}) 10}$ is available to aid in selecting the appropriate parachute.

After designing or selecting each element of the vehicle, the power required to fly the PPC through each part of the mission is determined. The flexible solar panels are then selected based on the selected parachute and the estimated power requirements. These panels will add weight to the vehicle, which should be considered during the calculation of the total weight of the PPC. This process is illustrated in Figure 2. 


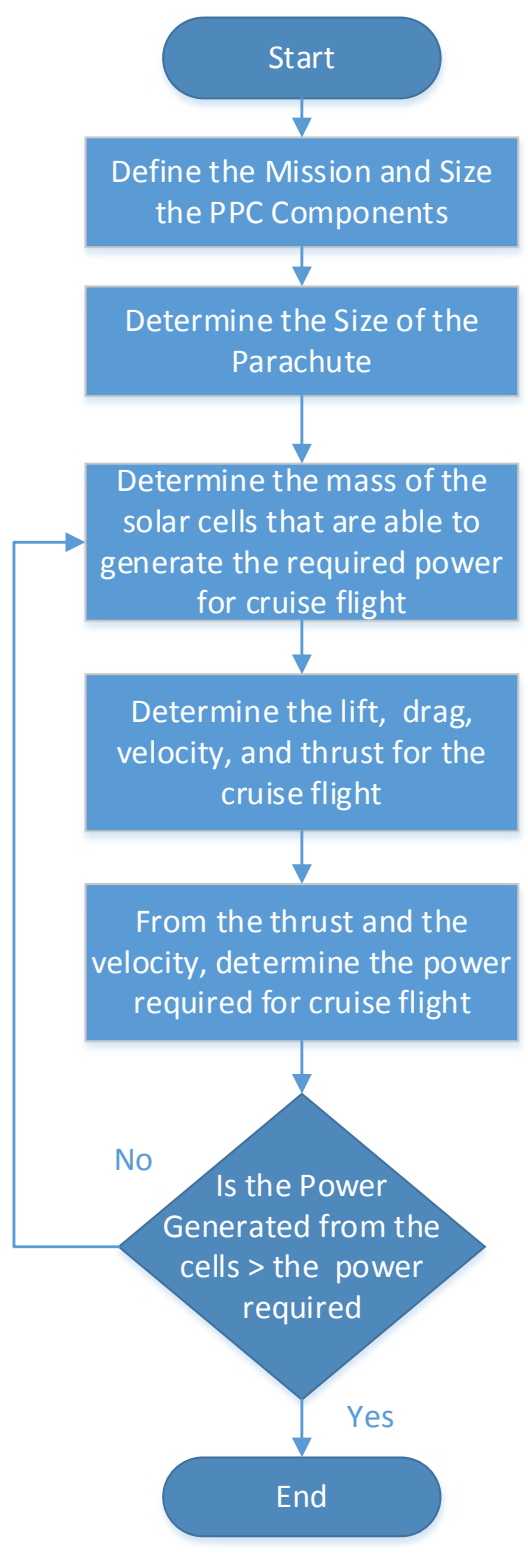

Figure 2. The iterative process of sizing the parafoil and the solar cells.

During the take-off phase of the PPC vehicle, the battery is fully charged. The PPC can thus commence flight without the need to draw power from the solar cells. Similarly, during the landing phase, the PPC does not require the power generated from the solar cells as the vehicle can land safely depending on its potential energy. Thus, in his work, we will consider powering the PPC vehicle during the cruise flight only.

For unaccelerated level flight (cruise) with velocity $V$, the lift force from the parachute, $L$, must be equal to the weight of the vehicle, $W$, therefore:

$$
W=\left(m_{v}+m_{s}\right) g=L
$$

Where: $m_{\mathrm{v}}$ and $m_{\mathrm{s}}$ are mass of the PPC vehicle and the mass of the solar cells respectively.

The lift force can be expressed as:

$$
L=\frac{1}{2} \rho V^{2} S C_{L}
$$

Where

$\rho$ is the density of air.

$S$ is the projected surface area of the parafoil.

$C_{\mathrm{L}}$ is the lift coefficient of the parafoil, which depends on the type of the airfoil and the angle of attack

During the straight level flight, the thrust force is equal to the drag force from the vehicle fuselage $\left(D_{\mathrm{f}}\right)$ and the drag force from the parafoil $\left(D_{\mathrm{p}}\right)$. Therefore, therequired thrust can be estimated from the following equation:

$$
T=D_{f}+D_{p}
$$

The parafoil drag force can be determined by the following equation:

$$
D_{p}=\frac{1}{2} \rho V^{2} S C_{D}
$$

Where: $C_{\mathrm{D}}$ is the drag coefficient of the parafoil

Based on the choice of the motor and the propeller that can produce the calculated thrust, we can determine the power required during the uncelebrated level flight from the following relation:

$$
P_{R}=T\left(V+v_{i}\right)
$$

where $v_{\mathrm{i}}$ is the induced velocity from the propeller which is given by

$$
v_{i}=-\frac{V}{2}+\sqrt{\left(\frac{V}{2}\right)^{2}+v_{h}^{2}}
$$

$\mathrm{v}_{\mathrm{h}}$ is the induced velocity when $V=0$, which is given by

$$
v_{h}=\sqrt{\frac{T}{2 \rho A}}
$$

$A$ is the disk area which is given by

$$
A=\pi R^{2}
$$


where $R$ is the radius of the propeller.

The power calculated from Equation (3-5) is ideal, the actual power can be calculated from

$$
P_{\text {req }}=\frac{P}{\eta}
$$

Where $\eta$ is total efficiency of the motor-propeller combination which is nearly 0.75 .

The above equations can be used with the flowchart, presented in Figure 2, to estimate the weight and area of solar cells needed to provide the PPC vehicle with the required power.

The small PPC shown in Figure 3 can be used to conduct our study since most of its main characteristics are available. These values are shown in Table $1^{11}$.

The thrust $(T)$ from the electric brushless DC motor is determined experimentally as ${ }^{11}$ :

$$
T=3.298^{\star} 10^{-7} \Omega^{2}-1.187 * 10^{-3} \Omega+1.3805
$$

Where $\Omega$ is the motor speed given in terms of revolution per minutes (RPM)

Similarly, the parafoil drag is determined experimentally and is given by:

$$
D_{p}=0.025 \mathrm{~V}^{2}+0.249 \mathrm{~V}
$$

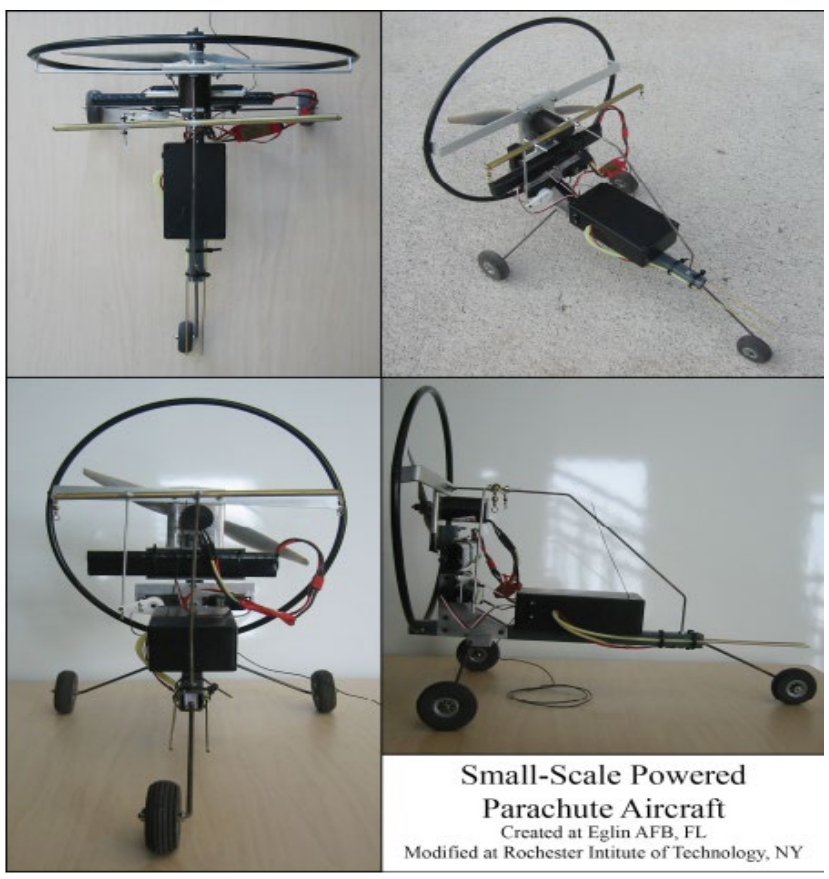

Figure 3. Small PPC Model ${ }^{11}$.
Table 1. PPC Model Characteristics

\begin{tabular}{|l|l|}
\hline Mass of the Canopy & $1.662 \mathrm{Kg}$ \\
\hline Mass of the Parafoil & $0.26 \mathrm{Kg}$ \\
\hline Total Mass $\left(m_{\mathrm{v}}\right)$ & $1.9 \mathrm{Kg}$ \\
\hline Cruise Speed $(V)$ & $7 \mathrm{~m} / \mathrm{sec}$ \\
\hline $\mathrm{C}_{\mathrm{L}} / \mathrm{C}_{\mathrm{D}}$ & 3.5 \\
\hline Fuselage Drag Force $\left(D_{\mathrm{f}}\right)$ & $2.5 \mathrm{Newton}$ \\
\hline Parafoil Area $(S)$ & $2.64 \mathrm{~m}^{2}$ \\
\hline Max. Thrust & $10 \mathrm{Newton}$ \\
\hline Propeller diameter & 12 in \\
\hline
\end{tabular}

The lift force from the parafoil was alsoobtained experimentally and it is given by:

$$
L=0.385 V^{2}
$$

\section{Solar Panels Survey}

An extensive survey on solar cells available in the market was conducted. The survey focused on the flexible solar cells that have a potential to be fixed on a curved surface like the parafoil. Three types of flexible solar cells were identified. The first type is commonly used in fixedwing airplanes and other applications that have flat or non-flexible curved surfaces. This type is manufactured by Maxeon Sunpower ${ }^{R}$ and the material used in it is monocrystalline silicon. These solar cells are available at reasonable price. Unfortunately, when tested, they were found to be very brittle and were unable to support minimal bending moments. The second type of solar cells was found to be quite expensive. The manufacturing company Alta Devices ${ }^{\mathrm{R}}$ claims that its solar cells have high power to weight ratio and completely flexible ${ }^{12}$. The third type is very flexible and easy to install on acurved surface, but its efficiency is low compared to the other two types. The characteristics of these three types of solar cells are shown in Table 2.

\section{Numerical Results}

\subsection{Power Generation for Cruise Flight Only}

For the uncelebrated level flight (cruise) and with a cruise speed of $7 \mathrm{~m} / \mathrm{sec}$, the drag force for the PPC vehicle is about 5.5 Newton $^{11}$. Therefore, the power required to fly the PPC in this flight condition is 46 Watt. Adding the 
Table 2. Characteristics of the sollar cells

\begin{tabular}{|c|c|c|c|c|}
\hline Characteristics & $\begin{array}{l}\text { Maxeon }{ }^{\mathrm{R}} \text { Sunpower Solar } \\
\text { Cells }^{12}\end{array}$ & Alta Devices ${ }^{\mathrm{R}}$ Solar Cells ${ }^{13}$ & $\begin{array}{l}\text { InfinityPV } \\
\text { Solar Tape } \\
\text { Sola }^{14}\end{array}$ & Unit \\
\hline Flexibility & Semi-Flexible & Flexible & Flexible & \\
\hline Area of each cell & $(125 \mathrm{mmX} 125 \mathrm{~mm}) 0.0156$ & $\begin{array}{l}(50 \mathrm{mmX} 22 \mathrm{~mm}) \\
0.0011\end{array}$ & $\begin{array}{l}106 \mathrm{mmX} 1000 \mathrm{~mm}) \\
0.106\end{array}$ & $\mathrm{~m}^{2}$ \\
\hline Weight per area & 512 & 174 & 220 & $\operatorname{gram} / \mathrm{m}^{2}$ \\
\hline Max. Power of each cell & 3.2 & 0.21 & 3.18 & watt \\
\hline Power per area & 120 & 250 & 30 & Watt $/ \mathrm{m}^{2}$ \\
\hline Power per $\mathrm{Kg}$ & 235 & 1437 & 136 & Watt/Kg \\
\hline Price & 160 & 25000 & 1200 & Dollar/m $\mathrm{m}^{2}$ \\
\hline & & $22 \mathrm{~mm}[\underbrace{50.5 \mathrm{~mm}}_{\substack{\text { Single Cell } \\
(0.96 \mathrm{~V}, 0.21 \mathrm{~W})}}$ & & \\
\hline
\end{tabular}

solar cells increases the vehicle mass and consequently the required power. It is assumed that the same parafoil with area $S=2.64 \mathrm{~m}^{2}$ is used and the solar cells are installed on the upper surface of the parafoil. By using the chart in Figure 1 and the data in Tables 1 and 2, the areas and masses of the solar cells can be estimated, Figures 4-5. Table 3 shows the areas and masses of the solar cells needed to provide the PPC model with the required

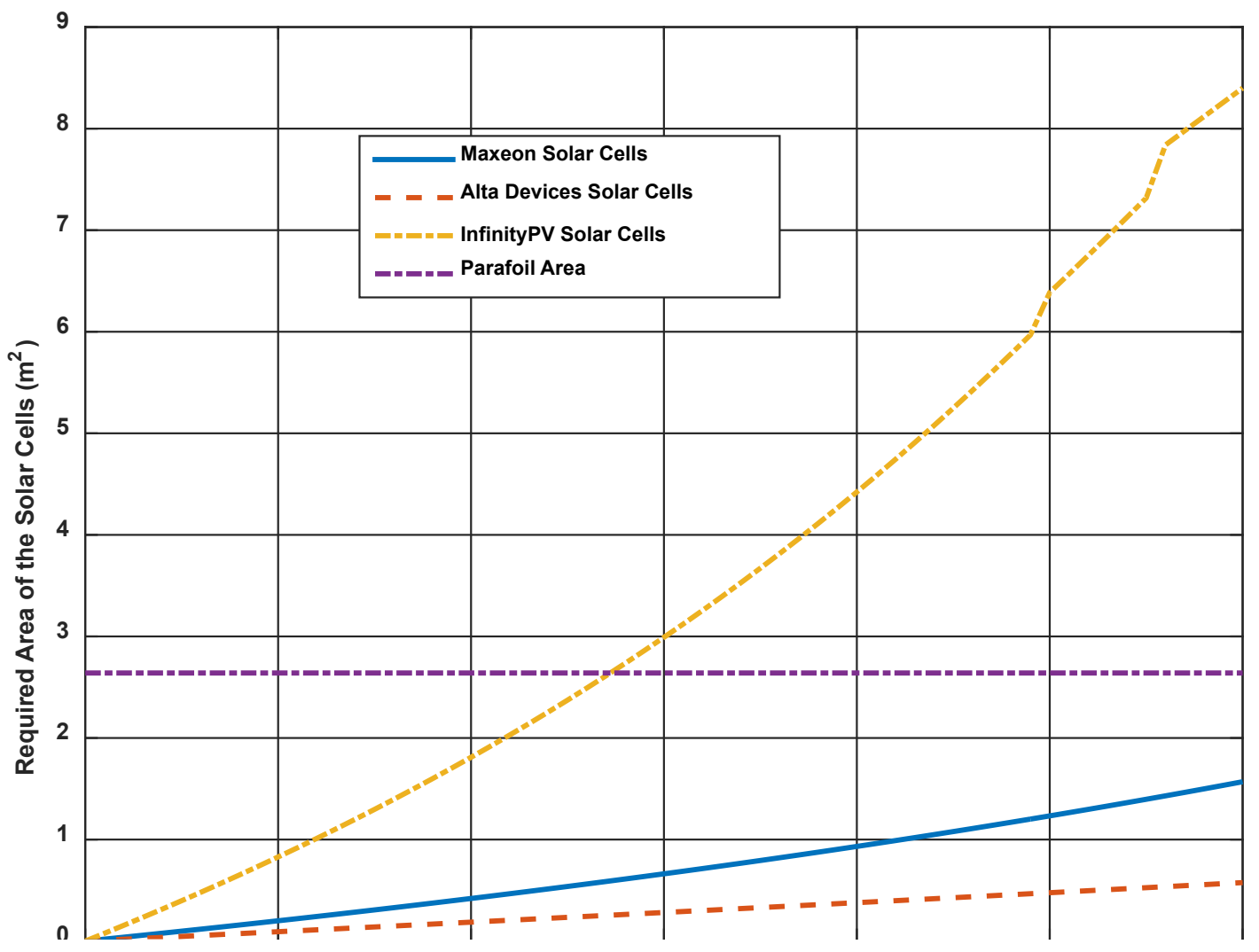

Figure 4. Variation of the solar cells area with the generated solar power. 


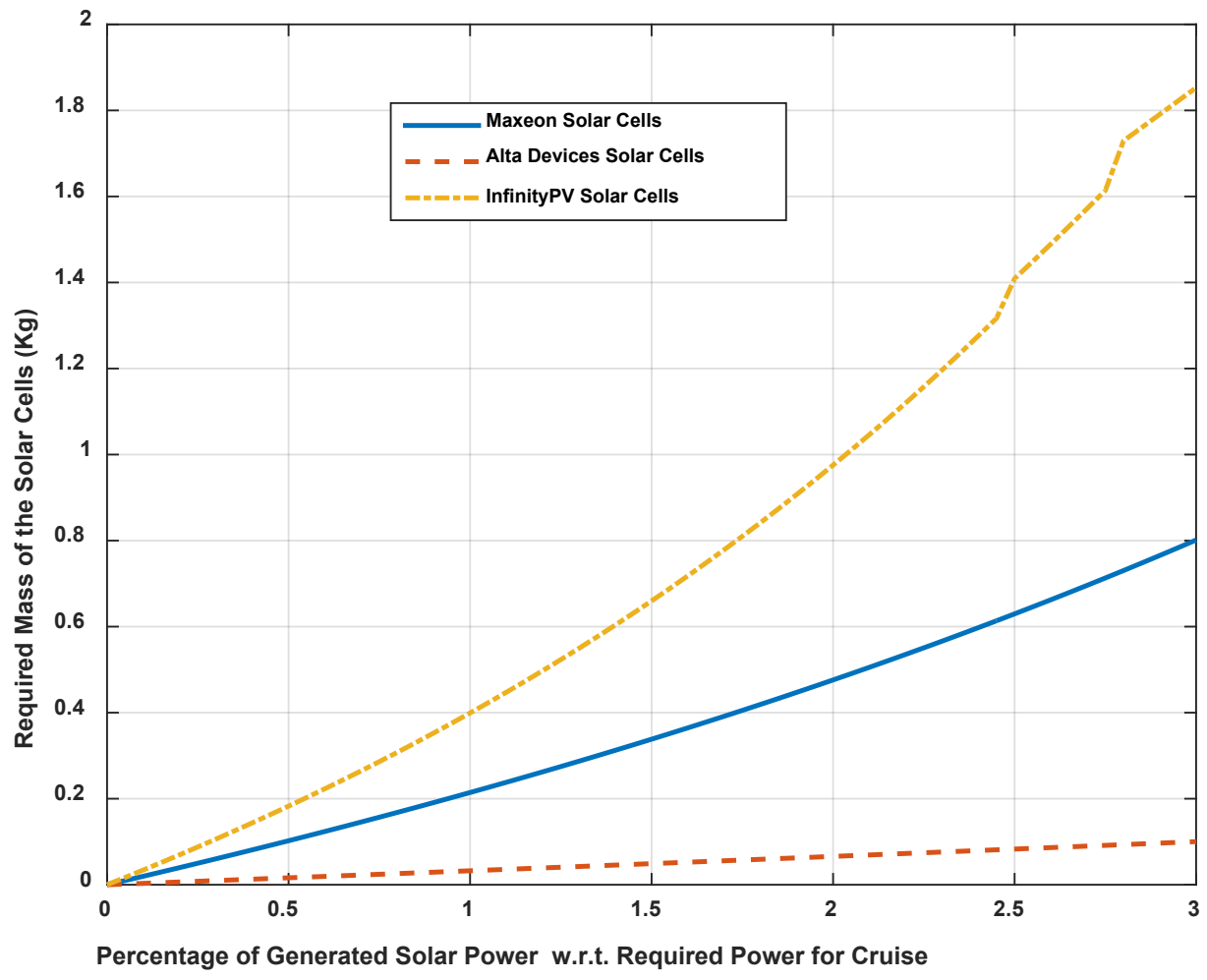

Figure 5. Variation of the solar cells mass with the generated solar power.

Table 3. Power from the Solar Cells

\begin{tabular}{|c|c|c|c|c|}
\hline Quantity & $\begin{array}{l}\text { Maxeon }^{\mathrm{R}} \text { Sunpower } \\
\text { Solar Cells }{ }^{12}\end{array}$ & $\begin{array}{c}\text { Alta Devices }{ }^{\mathrm{R}} \text { Solar } \\
\text { Cells }^{13}\end{array}$ & $\begin{array}{l}\text { InfinityPV } \\
\text { Solar Tape }\end{array}$ & Unit \\
\hline Required power without the solar cells & 46 & 46 & 46 & watt \\
\hline PPC Velocity with the solar cells & 7.4034 & 7.0602 & 7.7464 & $\mathrm{~m} / \mathrm{sec}$ \\
\hline Required thrust with the solar cells & 5.7137 & 5.5041 & 5.9290 & $\mathrm{~N}$ \\
\hline Motor speed with the solar cells & 5831 & 5752 & 5911 & RPM \\
\hline Required power with the solar cells & 50.3774 & 46.6560 & 54.3010 & watt \\
\hline Required solar cells area & 0.4198 & 0.1866 & 1.81 & $\mathrm{~m}^{2}$ \\
\hline Required solar cells mass & 0.2144 & 0.0325 & 0.3993 & $\mathrm{Kg}$ \\
\hline Area ratio (Solar Cells/Parafoil) & $16 \%$ & $7 \%$ & $69 \%$ & \\
\hline
\end{tabular}

amount of power that enable it to operate in cruise flight without saving any additional power in the battery.

As shown in Table 3 and Figures 4-9, all the three types of the solar cells can provide the necessary power to fly the PPC model. However, the first type is not flexible enough to withstand the bending moments that is expected during flight. The second type is powerful and has the lowest weight but it is extremely expensive. The third type is very flexible but has the lowest power efficiency and its price is moderate compared to the other two types. Table 3 and Figure 4 also indicates that there is additional room on the parafoil surface to install more solar cells and therefore produce more energy which could be stored and used during night flight.

\subsection{Generation of Additional Power over Cruise Flight Power}

As indicated in Figures 4, there is additional room to add solar cells so that additional power can be generated for night flight. It is noted that adding more solar cells will 


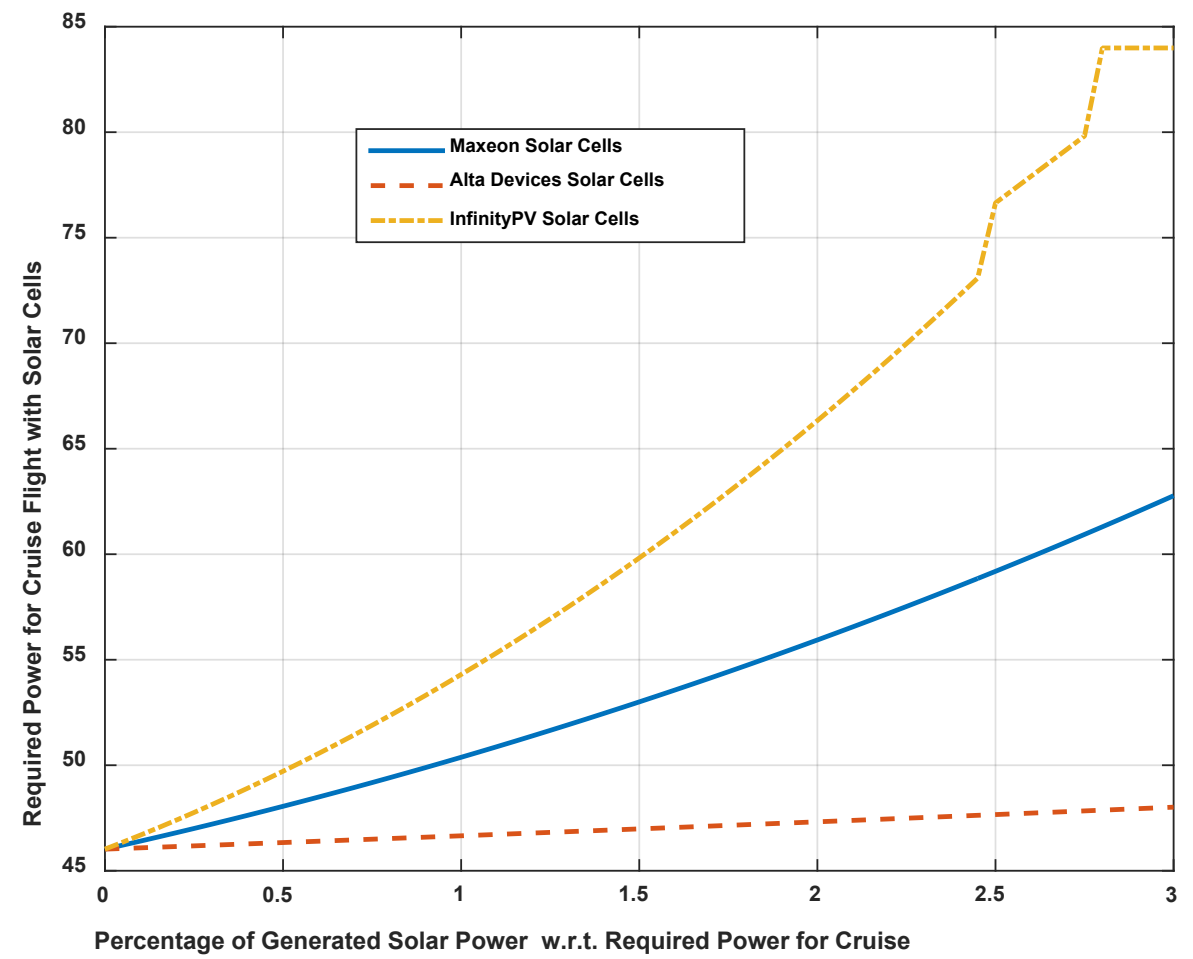

Figure 6. Variation of required power for cruise with the generated solar power.

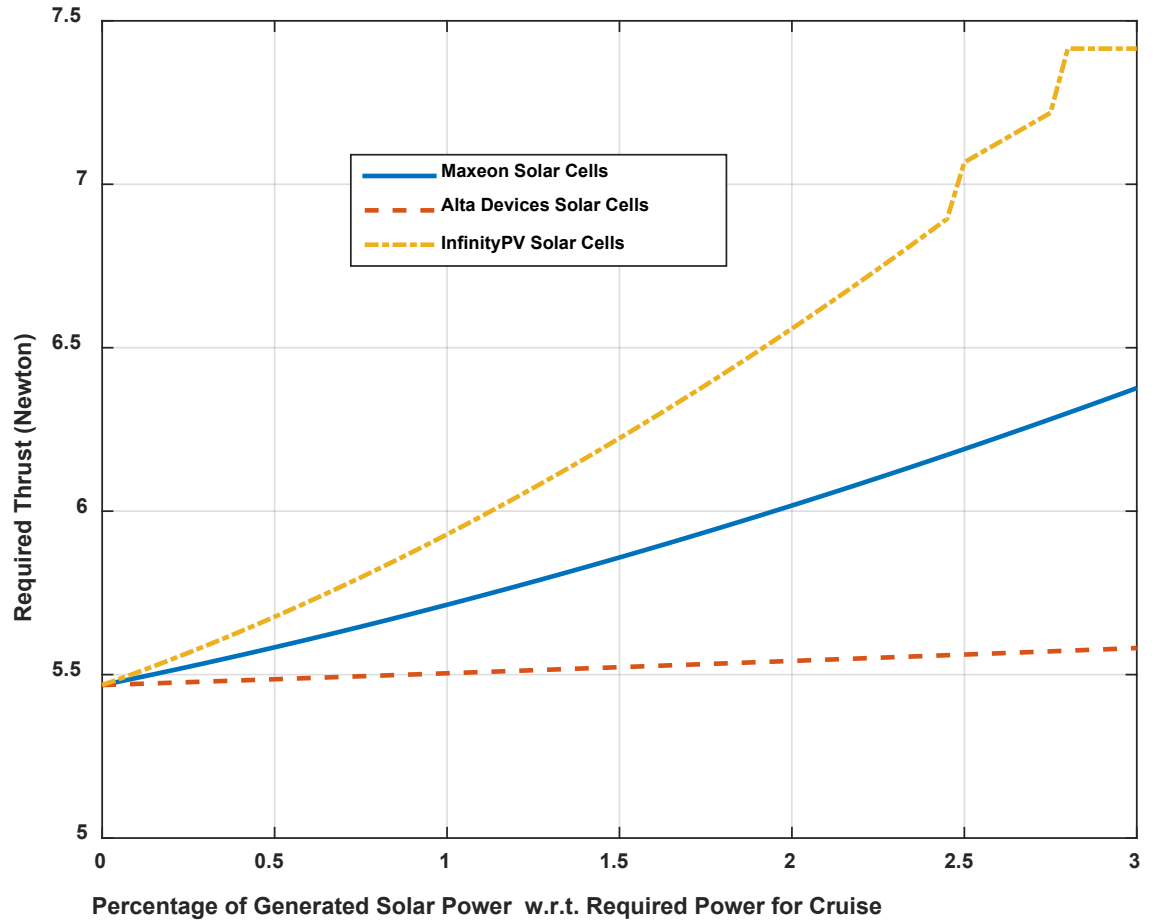

Figure 7. Variation of required thrust for cruise with the generated solar power. 


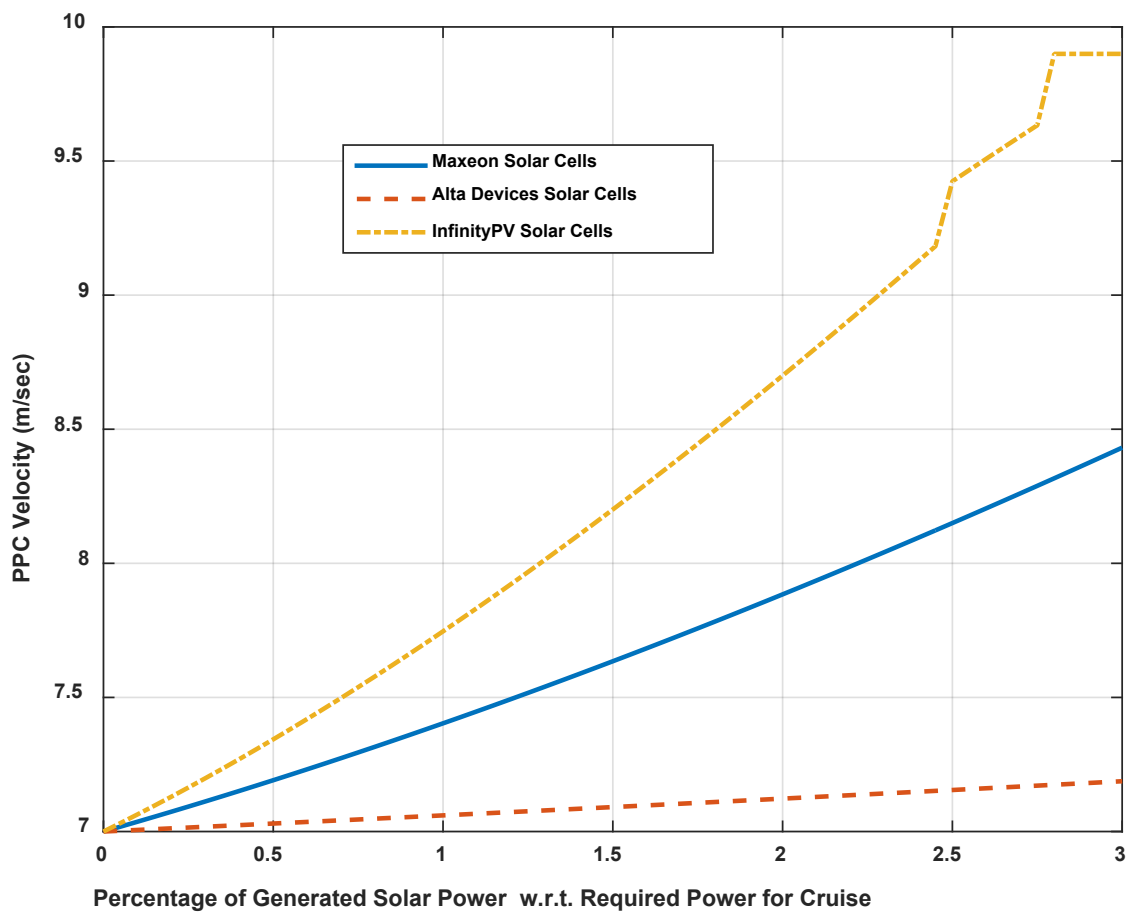

Figure 8. Variation of PPC velocity for cruise with the generated solar power.

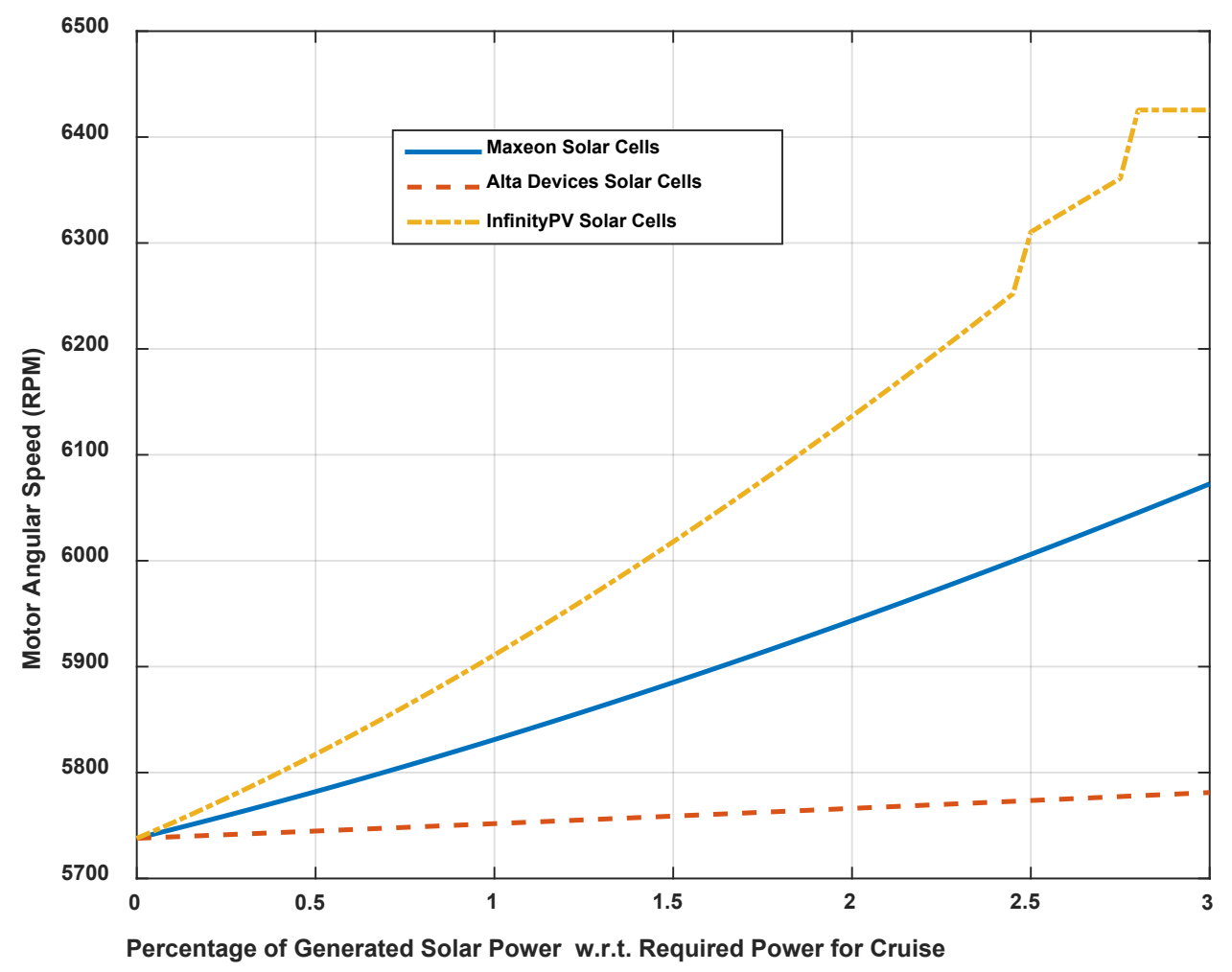

Figure 9. Variation of motor angular speed for cruise with the generated solar power. 
increase the mass of the PC and thus affect the required power for cruise flight which will have to be determined with the procedure illustrated in Figure 2. Several scenarios when additional solar cells are added are discussed.

Figures 4-8 show the variations of the PPC main variables with the percentages of the generated power from the solar cells with respect to the power required for cruise flight. It is observed from Figure 4 that the InfinityPV ${ }^{\mathrm{R}}$ solar cells cannot produce more than 1.3 of the solar required for the cruise flight otherwise the required solar cells area will exceed the area of the parafoil. It can be noticed also from these figures that the required solar cells mass and consequently the required power for cruise flight as well as the thrust and the motor angular speed increase dramatically with increasing the generated power from the solar cells.

The increase of the Maxeon ${ }^{\mathrm{R}}$ solar cell area and mass are small compared to the Infinity $\mathrm{PV}^{\mathrm{R}}$ solar cells. So, a high percentage of power can be produced without exceeding the parafoil area. So, nearly this type of solar cells can produce up to $425 \%$ of the power required for cruise and therefore can be used to fly the PPC during day and night.

The best performance can be obtained from the AltaDevices ${ }^{\mathrm{R}}$ solar cells. The percentage of the generated power is high and the additional mass of the solar cells to the vehicle is relatively small. So, $400 \%$ of the powered needed for cruise can be produced from this type of solar cells without a substantial change in the original PPC characteristic such as the mass, thrust, speed, cruise power, and the motor angular speed.

\section{Conclusion}

A feasibility study was conducted to assess the potential of using solar cells to provide a powered parachute model with the necessary power to operate it during the cruise flight. Three types of solar cells which are commonly used in the market were considered in this study. It was found that the three solar cells can generate the required power. However, the first of these solar cells are not flexible enough to be fixed on the curved surface of the parafoil. On the other hand, the second type is extremely expensive to be used with this low-cost flying vehicle. The third type is flexible with low efficiency and its cost is moderate compared to the other types. So, we recommend the third type of solar cells to be installed on the curved surface of the parafoil in order to provide the powered parachute vehicle for the most of its required power during cruise flight.

\section{Acknowledgment}

This work is funded by Qassim University under project \# 1342-qec-2016-1-12-s.

\section{References}

1. Powered Parachute. Available from: crossref. Date accessed: 30/03/2018.

2. PPG Industries. Available from: crossref. Date accessed: $21 / 4 / 2018$.

3. Boucher RJ. History of solar flight. AIAA 84-1429, Proceedings of the 20th Joint Propulsion Conference, Cincinnati, Ohio, USA. 1984. crossref.

4. Vashishtha V, Kumar A, Makade R, Lata S. Solar power the future of aviation industry. International Journal of Engineering Science and Technology. 2011; 3:2051-8.

5. MacCready P, Lissaman P, Morgan W, Burke J. Sun-powered aircraft designs. Journal of Aircraft. 1983; 20(6):487-93. crossref.

6. Abbe G, Smith H. Technological development trends in Sola powered Aircraft Systems. RSER Renewable and Sustainable Energy Reviews. 2016; 60:770-83. crossref.

7. Schoeberl E. From Sunrise to Solar-Impulse 34 Years of Solar Powered Flight. Technical Soaring. 2008; 32(4):11521.

8. Noll T, Brown J, Perez-Davis M, Ishmael S, Tiffany G, Gaier M. Investigation of the Helios prototype aircraft mishap. Mishap Report. 2004; 1:1-100.

9. Surfplan. Available from: crossref. Date accessed: 08/2017.

10. Chambers J. Longitudinal dynamic modeling and control of powered parachute aircraft. Master Thesis, Rochester Institute of Technology Rochester, New York. 2007; p. 1-142.

11. SunPower C60 solar cells. Available from: crossref. Date accessed: 21/4/2018.

12. Organic solar cell, InfinityPV. Available from: crossref. Date accessed: 09/4/2018. 